\title{
Women's Disintegrated Participation: Hierarchy and Gender Relations Re-Examined in Khru Somsri
}

\author{
Porranee Singpliam \\ (ภรณี สิงหเปลี่ยม) \\ Ph.D. Lecturer, Bachelor of Arts Program in Language and Culture (BALAC) \\ Porranee.S@chula.ac.th
}

\begin{abstract}
The reality of global capitalism and development ideology has made Thailand uncertain. In the 1980s, Thailand's reduced political activity accelerated the export-oriented economy. The move in policy from political control to development ideology for the pursuit of economic advancement can be argued to have presented a collective threat to the people. The economic disparity prevalent in Thai society shows that people at the community level must face hazardous and insecure treatment from the more dominant party. In this paper, I have conducted an in-depth analysis of the film Khru Somsri (1986) which is a "social mirror" of Thai society amid this economic growth. I argue that statist development ideology, which is interchangeable with modernity, engenders two things. They are, firstly, the discourse on participation pertaining to class and gender and, secondly, the empowerment discourse, particularly of women. This paper shows that people at the local level must struggle in order to prolong their survival in the slum community. Furthermore, how the discourse of participation is being maneuvered is manifold. Participation, as seen in this film, is hierarchical and gendered. The latter aspect of gender relations amid the accelerated market economy ultimately challenges the propriety of how Thai women embody their femininity. This paper re-examines the enmeshed affiliations between the development discourse and disintegrated participation with special attention to gender relations where women's participation in the development discourse unveils them as ardent, impassioned actors and empowered women.
\end{abstract}

\section{Keywords}

development - participation - femininity

(C) PORRANEE SINGPLIAM, 2019 | DOI:10.1163/26659077-02201003

This is an open access article distributed under the terms of the prevailing CC-BY-NC License at the time of publication. 


\section{บทคัดย่อ ความร่วมมือที่ไม่เท่าเทียม ความเหลื่อมล้ำ และเพศสภาพในภาพยนตร์ เรื่องครูสมศรี}

ความเป็นจริงเรื่องระบบทุนนิยมโลก (Global Capitalism) และอุดมการณ์การพัฒนา ก้าวหน้า (Development Ideology) ทำให้ประเทศไทยตกอยู่ในสภาวะแห่งความไม่ แน่นอน ในช่วงทศวรรษที่ 1980 กิจกรรมทางการเมืองที่ลดน้อยลงในไทย ส่งผล ให้เกิดเศรษฐกิจส่งเสริมการส่งออก การเปลี่ยนแปลงนโยบายจากการคุมอำนาจ ทางการเมืองไปเป็นอุดมการณ์การพัฒนาเพื่อส่งเสริมความก้าวหน้าของเศรษฐกิจ นั้น ถือเป็นข้อโต้แย้งได้ว่า เป็นภัยคุกคามต่อประชาชน ความเหลื่อมล้ำทางสังคม ที่ปรากฏในสังคมไทยแสดงให้เห็นว่า ประชากรชนชั้นรากหญ้าต้องเผชิญกับการ ปฏิบัติที่ถูกเอาเปรียบและไม่ปลอดภัยจากฝ่ายที่มีอำนาจมากกว่า งานวิจัยนี้นำเสนอ การวิจัยเชิงลึกจากภาพยนตร์เรื่อง ครูสมศรี ซึ่งเป็น “กระจกสังคม" สะท้อนสังคม ไทย ท่ามกลางการเจริญเติบโตของเศรษฐกิจ อุดมการณ์การพัฒนาของรัฐ ซึ่ง คล้ายกับความคิดสมัยใหม่ (Modernity) ส่งผลสองประการคือ เป็นทั้งวาทกรรมที่ก่อ ให้เกิดส่วนร่วม และการเสริมสร้างอำนาจ โดยเฉพาะสำหรับผู้หญิง งานวิจัยนี้มีจุด ประสงค์เพื่อแสดงให้เห็นว่า ชนชั้น รากหญ้าจำเป็นต้องดิ้นรนเพื่อความอยู่รอดใน สภาพแวดล้อมสลัม นอกจากนี้ การมีส่วนร้วมทางวาทกรรมมีหลายรูปแบบและจาก หลายฝ่าย ซึ่งในภาพยนตร์เรื่อง ครูสมศรี การมีส่วนร่วมยังมีการแบ่งแยกทางชนชั้น และเพศสภาพ ในส่วนของเพศสภาพท่ามกลางการเจริญเติบโตของเศรษฐกิจนั้น ท้าทายคำนิยามของคำว่าความเป็นหญิงไทย

\section{Introduction ${ }^{1}$}

Thailand encountered an enormous backlash during the socio-economic disruptions of global capitalism, development and the country's agricultural transformation in the late twentieth century. As a result of the rapid growth of a capitalist market economy, there was an evident disparity between socio-economic classes and gender relations. As a form of social realist film reflecting the socio-cultural transformation of the time, Khru Somsri (1986) represents empowered women as the backbone of the struggle that dominated the eighties. The rhetoric of development (kan phatthana) not only enforces women's participation in the political arena-defending their community-but it also actualizes their position and role sanctioned by Thai society and culture in this changing economic yet stable political terrain. It is not surprising that

1 This paper is part of the author's Ph.D. dissertation titled "Women and Nation: Historicizing Thai Femininity from 196os-1990s". I would like to thank the reviewers of this article for giving me abundant ideas and suggestions for the revision. 
the representation of Thai women during this period centers on intrepid and audacious characteristics. But, what is notable is that the stark opposition to the said characteristics is also depicted in the selected film. The propriety of female sexuality is challenged in the development discourse. It leads to both participation and desperation for the women who, unfortunately, have obligations to filial piety and prolong their families' sustenance. Women participants at the community level must fight against the degenerated patronage system that upholds the power of the state and its patron. The process of Othering is twofold in the sense that the Other is sardonically no other than the Thai elites themselves. At the same time, the other exists in another form of class-based gender and is a discriminated class. The latter is being othered and forsaken at the expense of the neo-liberalist economic approach. Altogether, Khru Somsri unearths the detriment that the development discourse brings to the local community, class structure and the reification of women's position and role in decade of the economic miracle.

2

\section{Stability and Economic Fortune}

According to McNabb (1988:224), Thailand's political state in the 1980s was that of "relative stability". One of the main factors that led to this rather stable period in comparison with the previous decades was the lack of political turbulence. McNabb provides several reasons for the lack of political activity. Firstly, there was Prime Minister Prem Tinsulanonda's robust rule and the amnesty provisioned for the Communist Party of Thailand (CPT) insurgents on their return from the jungle. ${ }^{2}$ Secondly, there was an election that permitted ex-adversaries of the state to take part in political activity. Thirdly, the debilitating support for the СРт both internally and externally resulted in ideological collisions among the CPT insurgents themselves. ${ }^{3}$ Fourthly, there was the military section's unwillingness to stage a coup. Combined, these factors led to a pretty steady decade in terms of politics and this resulted in development that focused on the rapid growth of the economy. ${ }^{4}$

2 See Thongchai Winichakul (2002) "Remembering/Silencing," p. 254.

3 See Thongchai Winichakul (2002) "Remembering/Silencing," p. 259.

4 See Gail Omvedt (1986), "Women in Popular Movements: India and Thailand during the Decade of Women," p. 238. Peter F. Bell (1997), "Thailand's Economic Miracle: Built on the Backs of Women," p. 55. Patsorn Sungsri (2004), Thai Cinema as National Cinema: An Evaluative History, p. 154. 
How did economic fortune affect the socio-cultural formation of people in Thailand in the eighties? The literature discussing the economic prosperity of Thailand in this decade seems to agree that this prosperity either created affluence for a certain group (class and gender) or engendered a new rhetoric of economic growth. The latter was performed through what Reynolds (2002:309) quotes as a strategic "siamization of capitalism ... from within". This emphasised localisation and the return to community in order to extol the Thai identity on the world stage-for it to be consumed by the Others. Reynolds (2002) and Busbarat and Creak (2015) emphasize the age of economic consumption's possible threat to the Thai people collectively. However, going back to locality ${ }^{5}$ signifies the contradictory idea that only when the influence of Western capitalistic values enters the country does the rhetoric of locality then emerge. Economic growth affects not only the socio-cultural factors of Thai people but it also affects the ideological terrain as well.

In Thai Identity in the Age of Globalization, Reynolds (2002:329) explains clearly that production driven by capitalist principles extensively enhanced people's motive to become more materialistic but groups of academics or activists responded to the economic boom by going back to their roots or the locality. It can be said that the move to return to their roots or "localization" resulted from what Reynolds (2002:332) terms as the "threat to sovereignty." Hence, the emergence of the local, the village and the community became the main focus of the decade. As a challenge to the hegemony of Western capitalist values, the principle of self-reliance emerged in the eighties. The advocates of self-reliance discourses believed that a solution to the market-led economy could be found in rural areas where the local community and local culture was able to prosper without the interference of the materialistic values that come with the discourse of development.

It should be emphasized that the development discourse, which strengthens class-based economic disparity, is felt the most at the grassroots level amongst those who are more or less devoid of political power to speak effectively or act against the state's development plan. In effect, the local level does not have the

5 The literature written on this rhetoric also refers to the Thai neologism of locality that connotes authentic Thainess as phumpanya. See also Craig J. Reynolds (2002), "Thai Identity in the Age of Globalization," p. 329. Pongphisoot Busbarat and Simon Creak (2015), "Re-Examining Self-Reliance: Collective and Individual Self-Making in Rural Thailand since the 1980s," p. $338,35^{2}$.

6 Reynolds (2002:332) writes that due to the "economic warfare" [that was] being waged on the country by international financial institutions and the market, apprehension formed among some groups concerning the fact that the Thai identity was losing its significance. 
opportunity successfully to represent itself; its needs, demands and deficiencies are overlooked as a result of neo-liberalist ideology. Its voice is rendered mute in the changing political space. Does the rhetoric of localization speak for the village community and the locals then? I will show that Khru Somsri, represents the extension of insufficiencies among the local people in the form of lack of choice and opportunity due to market-driven ideology and at the same time, coerces them to become materialistic because of the development discourse being geared towards discursive market-driven practices.

3

\section{Community vs. Modernity}

The rhetoric of self-reliance-advocated by certain activists and academicsratifies the notion of solidarity to the point that it became stark opposition to the state's policy at the time. Tantiwiramanond and Pandey (1996:81) write "Thailand, enthusiastically embraced economic growth as the goal of their national policy". This policy was implemented in spite of the unreadiness of the people especially the majority in the rural and countryside areas where the economy's roots were agrarian based. ${ }^{7}$ The economic prosperity that made the rich become richer and the poor became poorer prompted NGOs to take another turn regarding the development (kan phatthana) of the economy that was more expedient for the rural dwellers. The most underdeveloped parts of the country which felt the economic gap the most were the nuclei where the self-reliance rhetoric was advocated.

According to Busbarat and Creak (2015:399) self-reliance is fundamentally a discourse acting as a counter response to the threat posed to collective Thai culture and the "failure of industrial or 'top-down' development". This leads to the emergence of two kinds of self-reliance: the collective and the individual. ${ }^{8}$ In both cases, this rhetoric discursively encourages the idea that the locals can utilize outside influence so long as they "use [it] wisely" (352). In spite of the ambivalence concerning to what degree people can adopt external influence

7 See Phongpaichit and Baker (1995) Thailand, Economy and Politics, p. 396.

8 Further, Busbarat and Creak (2015:340) delineate specifically the two types of self-reliance where the former is "village-based self-reliance [that] became valorized as something lost in the rush to modernize". The latter, collective self-reliance, on the other hand, is described as "a form of self-making [that] stresses the benefit of harnessing one's entrepreneurial spirit" (342) and to "actively engage with the market and the state" (343). With this statement, it is suggested that the statist discourse of development is being maneuvered to benefit the local individuals in spite of the acclaimed statement where some scholars tried to proclaim the state's and the locals' ostensible separation. 
that comes with modernity, it is certain that the collective kind of self-reliance perpetuates and prolongs the bifurcation between we and they, local Thai and the Other's influence, the authentic Thai and modernity. In a nutshell, it creates and strengthens solidarity in the "community' and 'village' ... under the threat from 'macro-scale' development" (340).

Due to the aforementioned rhetoric, it becomes clear that there is a separation between the locality's self-reliance on the one side and the state-led policy on the other. Accordingly, Tantiwiramanond and Pandey (1996:81) explain the latter as the "modernization [that was] synonymous with urbanization, industrialization and westernization". As I have mentioned earlier, the state-led policy on economic and social development under the name of the National Economic and Social Development Plan (NESDB $)^{9}$ did not do much to alleviate problems at the grassroots. ${ }^{10}$ On the contrary, it problematised issues such as human development and the people's well-being, specifically those in the agricultural bases.

Modernity and development are problems for local-advocates. Effectively, the community becomes a pivotal node that needs protection from the outside-the un-Thai. Haughton (2009:45) writes that because "little of this [economic] wealth seemed to percolate to the countryside" the NGOs found that they needed to "foster the capacity of rural villages to be self-sufficient" (46). It appears that 'self-reliance' and 'self-sufficient' counter ideologies will be circulated and repeated as long as there is evidence of an encounter with Other discourses due to the influx of the globalized world. But, can the we and they be separated? Can the rural/community/village be self-sufficient without help or guidance from the outside world?

\section{4}

\section{Community and Modernity}

The idea of community, according to Reynolds (2009:29) strengthens the values of "solitary, total, natural" due to its underlying value of the Gemeinshchaft social situation. Unavoidably, the concept of 'solitary, total, natural' values categorizes those who belong to the community as the 'we' group and thereby the 'not-we' is engendered. In previous decades, the not-we or the Others here

9 Tantiwiramanond and Pandey (1996) lead us to focus on the specific fifth and sixth plan that lasted until the year 1996 .

10 See Andrew Turton (1989a) "Thailand: Agrarian Bases of State Power," pp. 53-69, "Local Powers and Rural Differentiation," pp. 70-97, Napas Sirisumpan (2001) Thai Women's Status in the Period of 2 Decades after the International Women's Year (1975-1985), p. 45. 
would refer to Western Others who came into contact with Thais. But, due to a lack of political turbulence, the Other that defies the local community became none other than the Other within.

Turton (1989b:87-88) and Hirsch (1990:216) write that modernity, which interferes with the pattern of life and the community's modes of economy, does not entirely separate modernity vis à vis the community. The manner in which state-led modernity perpetuates its influence and neo-liberalist economic practices into the locals is through "coercion". This will be elaborated later on with the inevitable materialization of Thai society as seen through the characters in the village community and with my focus on a female character in Khru Somsri. In fact, the state-led discourse of development that upholds modernity during the eighties collaborates with the locals on certain conditions. Those are the hierarchical position and connections and, most importantly, gender relations. The former hierarchized relation between the state and village people in higher positions (or closer connection with the state), represents what Hirsch (1990:201) terms as "patron clientage"11 or to use Turton's (1989a:63) term, "tripod structure". ${ }^{12}$ Thus, state-led development collaborated (in a complicit manner) with the selected few in the community, which led to an emergence of participation.

The hierarchical structure that upholds the power of locals-the selected few-created what Sungsri (2004:284) terms "local gangsters". Reynolds (2009:30) writes that the community itself already ratified the "aspect [of] community [as] an inclusive/exclusive fencing off outsiders by community members and the feeling of 'us' versus 'them'”. It is clear now that kan phattha$n a$ 's policy was embedded in modernity and that market-driven values seeped into the community. The community found a way to adapt or reject the Others' values completely. Either way, modernity made its way into the country regardless of the result. Walker (2009a:18) sums up brilliantly that, the "modern Tai community' is a deliberate attempt to subvert the assumption that modernity is opposed to community. [But the] community is being creatively reworked in modern political and economic contexts".

\footnotetext{
11 See Pasuk Phongpaichit and Chris Baker (1995:336) Thailand, Economy and Politics, for a detailed analysis, especially in the section titled "The Rise of the Provinces".

12 Andrew Turton (1989a:63) later wrote that the development discourse is an intertwined relationship that reveals the "dependence of Thai industrial conglomerates on foreign technology, foreign capital and imported machinery" i.e., the state, the locals and big capital. See further in Akira Suehiro (1992), "Capitalist Development in Postwar Thailand: Commercial Bankers, Industrial Elite, and Agribusiness Groups,” p. 37.
} 
Khru Somsri was released in 1986. It was written and directed by Mom Chao ${ }^{13}$ Chatrichalerm Yukol ${ }^{14}$ and won the 9th Suraswadi Award for the best lead actor. The film was nominated in other categories such as best director and best film. The storyline depicts the struggle of a slum community, Saan Trok Chao Pho Sua, against the Saha Phatthana Theedin Company, a land development company that would do anything to expatriate the community dwellers. In order to acquire the land to construct a department store, the company's representative-lawyer Sot-assigns a local gangster to lobby the impoverished individuals in the slum community and helps the company to expel the people with monetary inducements, giving away consumer goods or through the use of physical force.

However, the lead female character, Khru Somsri, does not give in to this coercion. Regardless of the harm done to the head of the community's committee, Chan, the negligence of the police force and bureaucracy, and the oppression by the powerful institution that leaves the dwellers unfed and penniless, Khru Somsri gathers the people and demands their right to live in the slum community. Towards the end of the film, lawyer Thongdee reveals that the state's personnel are the reason why Saha Phatthana Theedin Company is able to coerce illicit acts against the powerless people of the community. Lawyer Thongdee is subsequently gunned down along with Chan, and Khru Somsri herself. They all die as a result of their defiance of the powerful capitalist company, which, in this case, is the same entity as the state's personnel at the time.

The film provokes an urgent analysis of several issues. The first is the labyrinthine nature that characterizes a participation discourse that is advantageous on the one hand and disadvantageous on the other to a certain group of people. The former manifests itself in Hirsch's coinage as (1990:187) "the cheap and obedient labour of the poor at the disposal of the monopolizers". The latter is deemed to be a non-collaborative force from the community against the powerful capital/state. It is worth noting also that at the zenith of the

13 An official royal title-though the most junior rank-equated with prince.

14 Hamilton (1993:90) writes in regard to the affiliation between the film producers and the state that the censorship law prohibiting some issues on screen "could no longer be suppressed" due to "[t]he rise of the bourgeoisie, the increased level of education of the people, the struggles between mercantile capital and the dominant military and bureaucrats" which all led to the portrayal of hardships and injustices as a means of "ideological statements in reaction against the dominant forms" (91) by "the state and among the intellectuals, was prince Chatrichalerm" (90). 
economic growth, the time when the state adopted a liberal economic approach, the hegemonic economic policy further disseminated uneconomic disparities and unequal benefits to the people. The most affected were the grassroots. The eighties manifests a shift in the state's role from the stable institution that safeguards the people's well-being to suppressing their mobility for the sake of a neo-liberalist development contract. Due to this structural fragmentation, the participation of the village level is coerced by the state. The hierarchy embedded in the structural change muffles the people's voice and struggle, and renders their participation adjunct.

Moreover, it is significant to look at the empowered women who strategically participated in the development discourse and their relation to their roots and pride in their native community. Other female representation shows the deprived choice women have to face thereby restating their obligation to their families. As I will discuss in detail, rapid economic growth both prevented their leaving and further reified their socially sanctioned roles.

\section{Kan Phatthana and Participation}

Literature knowledge regarding the affiliation between the community and statist discursive practices on modernity argues that there is a separation in the working of community and the discursive practice of modernity. In spite of assumptions such as the one quoted by Walker (2009a:4) that there is a distinction between community and modernity when he writes that some perceive "the key forces that have brought about the fragmentation of the total Tai community are the market and the state" as if the two are dissociable, the anthologies in Tai Lands and Thailand: Community and State in Southeast Asia (2009) suggest that the two have a collaborative relation vis à vis the general assumption. The manner in which the locals conspire with the state-led discourse of development prolongs the status quo and never the other way around. Turton (1989b: 72-73) writes about the "new notion of development," wherein the "monopoly of which, politically and ideologically, lent legitimacy to an authoritarian staff, provided material support for ruling apparatuses" and at the same time engendering the materialistic needs among the locals as well.

Nevertheless, the state's assertion of power at the community level is never homogeneous. Even among the powerless, their participation with the discourse of modernity varies. In the film, we see that there are two stark opposites concerning this participation. On one hand, there is a group of hooligans who work with lawyer Sot to manipulate the community dwellers to sign the contract papers in favor of leaving their community without knowledge that 
they will not receive any compensation. They also go so far to physically threaten and injure the dissenters against Saha Phatthana Theedin Company's plan. The incentive for this clique of hooligans and the members of the community who sign the leave contract is money.

On the other hand, Hirsch (1990:216) states that there are "non-compliance" attitudes and actions from the community people which "d[o] not represent a neutral substitution of one type of control by another" (217). Khru Somsri leads the group of community's committees to challenge the land development company and, more importantly, to challenge the state's practices that seemingly contribute and sustain the capitalist's illegitimacy in dealing with the community and its people. The film shows that when Khru Somsri and her party travel to the office of the municipality to deplore their hardships or the event of their protest against the suspicious death of Chan, the community receives no help from the institution, especially the police. It should be emphasized here that the discourse of development that features participation is heterogeneous in its power but revolves around the stability of the status quo. Regardless of the manner in which the hooligans or Khru Somsri's party participate with or against the land developing company, the film shows that ultimately the company has a high chance of having the upper hand thereby being descriptive of the social reality in Thailand at the time. As Hirsch (1990:218) writes, the "decentralization of power in the name of participation ... merely [serves] to decentralize inequality and reinforce or reshape, rather than replace, 'non-rational' aspects of power and economic relations".

The condition of the rural poor dwellers in opposition to those in power reveals a totally different view towards the Other. In this case the Other, the enemy, the outside, the 'not-we', is the heavily capitalistic development policy. Given the stability of the political situation in this decade, the villain or the Other is deflected to none other than the Other within the country and, more precisely, within the community itself. In Khru Somsri, the local hooligans are the endemic gangsters that report to the Saha Phatthana Theedin representative, lawyer Sot. Further, the Other within the society, or more precisely, the Other alienating people within the society on a class-based criteria can be said to be the representative of the state-led neo-liberalism as well.

Accordingly, we need to ask, how do we analyze the state's adoption of a neo-liberalist policy which favors the free market, export-oriented economic enhancement and economic dependences with the world market? First, it portrays what I have expressed earlier, the capital-led inclination at the grassroots level, the only matter that would allow the dwellers in Saan Trok Chao Pho Sua community to evade is money. The community dwellers are coerced into the materialization of the society, in which, their wellbeing and hardships are at stake. 
Second, the role of the political guardian as played by the state in the beginning of the decade is transformed drastically via the adoption of a liberal approach. Connors (2004:160) writes that "liberals give priority to market freedom; the state is recognized as providing the regulatory framework necessary for the operation of a free market". I argue that the state grants domestic capital such as that of the Saha Phattana Theedin land development company to carry out its expulsion of the slum community so that they can construct a pivot for all things materialized, a department store. It reiterates the state's exploitation "at the expense of the poor" (176) and the inattention to the local people's hazardous living conditions.

The film reflects the situation at home regarding the state's approach on achieving the economic boom's effect on the powerless, the poor. It is what Sungsri (2004:274) terms "Nang sathorn sungkhom"15 where polemic issues or neglected problems of the grassroots are the central concern. The heart of Nang sathorn sungkhom or films reflecting society lies in the issues and concerns about the society and its people. Sungsri (2004:266) writes that this cultural form has oriented towards a new direction that "talk[s] about the essence of life and the misery of people such as prostitutes, slum-dwellers, and peasants". The depiction usually focuses on "the fate of poor people" as a direct effect and, to put it in Bell's (1997:60) words the "creators of the economy" of the marketdriven development policy. In the film, Boonpeng, the director of the office of the municipality's public service department tells a story about the hardships of the local people. Sungsri (2004:276) states that part of the emergence of the theme, which concerns socio-economic disparity, originated from Thais who had lived through the previous decade where arguably the global-driven market economy was put into full force. Along Sungsri's line of expression, Boonpeng could be said to represent "the 'new-generation' government official [as a] reflection of the ideals of young Thais in the 1970s, who became the middle class in the 1980s. The films reminded them of the Thai commitment to the poor". Boonpeng does not come from money and experiences the same loss of

15 Khru Somsri, in particular, I think was made to raise awareness and polemical issues in the society. Or to put in Hamilton's (1993:91) terms "the 'marginal' [is put] into the mainstream of [film] network". And, ironically, it is made concretized and visible by an elite filmmaker. Furthermore, Hamilton (1993:91) specifies that there was a direct political, social, and cultural intervention in the making of the films. As the discourse of development manifested its lack of care for the wellbeing of humanity, "the most popular films were of the nang chiwit or "drama," type, which appealed particularly to young women and focused on family, love and money, in the context of issues around tradition and modernity" in this period. 
his loved one as a result of the political incident. In this sense, Boonpeng, as a civil servant, participates and fights with the slum dwellers.

Lawyer Thongdee also lends a hand to the locals and gets himself killed as a result. He and Boonpeng attempt to expose the surreptitious support that the state personnel lent to the land developing company prior to the company's plan to construct the department store in this slum community. Although the deaths show the powerlessness of those who are antagonistic to the state, Boonpeng manages to go to trial and attains the legal rights for the slum dwellers and their community. This shows that power in society is asymmetrical and functions in complex and multifarious ways. The point is the discursive participation within the discourse of kan phatthana and the neo-liberalist economic growth policy is heterogeneous. It is heavily hierarchized where the grassroots' participative force is rendered auxiliary and their struggle on-screen is made laudable by a bourgeois filmmaker no less. In this film, as a reflection of the society, power in the Thai context is never static. As Vichit-Vadakan (1997:431) states, "it is a complex admixture of a multiplicity of accesses to realize various goals".

The participation at the level of the state, the community or the two combined is active and yet perpetuates a labyrinthine characteristic in the rhetoric of a modernity that is capitalist driven. Although the discourse of modernity urges collaboration, it is performed as long as the community and its dwellers can sustain their materialistic goals i.e., they need money to live, to educate themselves and to fight against the state. The transition into the economic affluence period as the state policy has it, is clearly influenced from the outside. This is reified by Haughton (2009:52) who states that the locals' adaptation occurred due to the "outside's consciousness". Further, Walker (2009a:18) writes in "Modern Tai Community" that "[o]ur choice of the term 'modern Tai community' is a deliberate attempt to subvert the assumption that modernity is opposed to community ... the way in which community is being creatively reworked in modern political and economic contexts".

The collaborative, resisting, coercive characteristic of participation reveals one thing that is central to kan phatthana; the male led and hierarchized characteristic of the discourse. The leader of the hooligans, the lawyers, the director of the public service department vis à vis Khru Somsri and other groups who Yuval-Davis (1997:45) terms "womenandchildren"16 ratify the

16 Yuval-Davis cites Cynthia Enloe (1990) terminology of "womenandchildren" where a particular social positioning is made for those of men and women. The terminology is applicable for Khru Somsri's character. She is a teacher and is often associated with the duty collectively centering around the small children at school. In Yuval-Davis' own words 
aforementioned gender relations with the development. ${ }^{17}$ Not only is power asymmetrical but it also strengthens the positionality of the classes and the expected roles of people of different genders. Women and their culturally sanctioned femininity waver and transform in this relatively stable political atmosphere. The opposition of the 'Madonna-whore' binary is perhaps the best terminology to describe Thai femininity in this decade.

\section{7}

\section{Kan Phatthana and Women}

The disparity between social strata, class and gender relations was heightened during the economic miracle, specifically, the discursive practices concerning economic growth that heavily focused on materialistic gains and forsook the role women have to perform. Indisputably, the rapid economic development of the 1980 s resulted in havoc being done to women. Omvedt (1986:238) writes that the "modernization, or uneven capitalist development ... not only [intensifies] existing class inequality but also gradually marginalizes women relative to men and subordinates their labour to international accumulation". 18

During this period, the assigned body and femininity only strengthened women's traditional role and their culturally expected obedience within many areas. In fact, Tantiwiramanond and Pandey (1996:93) write that "[t]he implementation of programs has been geared more toward improving the traditional role of women as wife and mother". It is not surprising that Khru Somsri

(1997:45) "the sake of 'womenandchildren' that men go to war ... collective imagination with children and therefore with the collective, as well as the familial, future". Despite the contexts that differ between Yuval-Davis' writing and the film, the vivid boundary is drawn where women were to be kept under the control and limited in their duty as a teacher so as not to overlap that of men's. She is to have proper femininity. Thus, when Khru Somsri acts otherwise, she is condemned by the local hooligans.

17 I would like to thank the reviewer who pointed out to me that we need to ponder the fact that the director/producer of this film is an elite bourgeois male who gets to portray the hardships of the grassroots level. Implicitly, the locals' struggle can be heard only by sentimentalized representation. The locals' voices were rendered unheard in the uneven development of Khru Somsri.

18 See Gail Omvedt (1986) "Women in Popular Movements: India and Thailand during the Decade of Women," pp. 211-247. Tantiwiramanond and Pandey (1987) "The Status and Role of Thai Women in The Pre-Modern Period: A Historical and Cultural Perspective," pp. 125-149, "New Opportunities or New Inequalities: Development Issues and Women's lives in Thailand" (1996), pp. 79-110. Peter F. Bell (1997) "Thailand's Economic Miracle: Built on the Backs of Women," pp. 55-82. Juree Vichit-Vadakan (1997) "Women, Men and Thai Politics," pp. 425-443. 
portrays female characters in the film as caretakers, teachers of small children, petty merchants and, most evidently, sexually submissive to a man of higher status and power. The portrayals of women's roles and position are suited to Vichit-Vadakan's (1997:435) analysis that they are "confined to the inner/ domains where their skills in domesticity were encouraged and elevated to the height of absurdity".

Female sexuality is also shown in the interaction between the hooligan's leader, Anek and his sister (the actress refers to Anek as brother or phi) and lawyer Sot. She is first introduced to him when she accompanies Anek to a furtive meeting with lawyer Sot. The meeting concerns how the two can dismantle the slum's antagonism towards Saha Phatthana Theedin. Anek offers his services and loyalty to the powerful company in return for money and protection. This female character has a scene with lawyer Sot where she retells the plans of the community's committee and their suspicion of Anek's task to gather the signatures in capitulation of the lands. This ends with her offering herself to the lawyer, never to be seen on the screen thereafter.

A number of scholarly works explain that in the rural areas (North and Northeast) of Thailand women hold more power and decision-making abilities. For instance, Pongsapich (1997:9) writes "data on the contemporary social structure indicates that in rural Thailand, patriarchy is not very prevalent". But, is this accounted for in the period of ascending economic growth and materialized society? A film reflecting society, such as Khru Somsri, suggests otherwise. Hardship and an inability to move upwards restrain women in their cultural expectations. When Khru Somsri rebelliously gathers people to fight against the capitalistic evil, she is seen as stubborn, radical and not to be underrated.

It is clear that the difference between the portrayals of the two characters, Anek's sister and Khru Somsri, offers insights in to how women differ even in the same social position. Thai women's status may seem rather well off in comparison to other Asian countries, ${ }^{19}$ but when the accelerated modern-led development brought materialistic sentiments to the country, the status and position of women encountered a major transformation. Tantiwiramanond and Pandey (1996:87) assert "[i]n order to understand how well Thai women fare in development, it is necessary to analyze them in the context of social

19 We need to be cautious regarding this claim. Some scholars contend that it is accounted for in comparison to countries such as India and China, for instance. Regardless, Shelly Errington (1990:7) makes clear that such a claim regarding the well-off status of Thai women is ambiguous specifically in as to what extent it is "well-off" in cross-cultural comparisons. 
and economic changes". The film therefore represents the status and assigned femininity concerning women's bodies in this decade.

The economic changes impinged upon women, more particularly those in the lower stratum. Bell (1997:57) writes that the "adoption of 'structural adjustment' programs in the 1980's, with [their] emphasis on export-oriented growth and tourism as sources of foreign exchange for industrialization" ultimately led to the "feminization of production". His argument is adamantly expressed along with the delineation of how women participated in the discourse of development. He contends that "Thai women produce vast amount of this growth" (64) in: industrial production, agricultural production, sexual service industry and the household economy and subsistence production. ${ }^{20}$ All of which indicates that despite the rather stable political period, women must adapt to keep up with the influx of new ideas about materialism and neoliberalist values which engender "the feminization of consumption" (70). This reifies the scene of Anek's sister's desires for mobility, as discussed in more detail below.

The sense of a consumption and money-led economy, however, permeates all genders at the community level in the film. A group of slum dwellers is unwilling to fight in court and resorts to signing the conceding contract giving up their lands. In return, they will receive monetary compensation from Saha Phatthana Theedin Company. One slum dweller asks Anek for affirmation, "Will we really receive the compensation money?" and with the confirmation, hopelessly, they sign. Another capitalistic yearning is portrayed on screen when Anek's sister visits lawyer Sot's office. She looks around, observes and, quite possibly considers, why she does not have all of this. In fact, she probably wonders how she can have this.

In a similar vein, Mills (1999:9) conducted an ethnographical research in a village community in Thailand during the economic affluence in the late $1980 \mathrm{os}$. Her results show that "women's needs" were also a significant premise concerning their rural-urban mobility. The source of such needs, Mills (1999:19) argues, is in accordance with the emergence of the media at the time. She further writes that, in fact, the perceived images of women and "women's bodies represent powerful images of modernity and moral degradation". But, what exactly are women's needs? To accommodate the accelerated capitalistic values and "being modern or up-to-date (thansamai)" (12), women were willing to work for low income, unaccommodating and repetitive types of jobs. These

20 For an in depth explanation on "the Feminization of Production" see Peter F. Bell (1997)

"Thailand's Economic Miracle: Built on the Backs of Women," pp. 65-70. 
included factory work and sexual work, for instance. ${ }^{21}$ To heighten the effect of the economic boom, the latter kind of job is emphasized in the film. Anek's sister cannot resist offering her sexuality to a man with a higher position and influence. By falling into the gambit of the capitalistic lure-materialistic accumulation-in this decade, female characters such as Anek's sister adhere to this particular pattern of femininity as a way of leaving their slum community. ${ }^{22}$

The offering of her sexuality in exchange for materialist gain, according to Bell's (1997:64) argument, is not merely "distributional impact and the inequality which capitalist growth generates". Anek's sister makes her choice not only because of the impact of development encroaching on the community but also as part of the "structural adjustment" (63) where women are "objects of (sexual) consumption" (63) in this economic miracle.

\section{Women's Disintegrated Participation}

However, not all women perform their femininity in the same way as Anek's sister. It is in this last section where I want to emphasize that the ramification of the economic boom is felt by women (even of the same level) in different ways. They are certainly victims of the development discourse and yet they also act against the discursive practices that deem them unable, radical and inapt for Thai women in this particular historical setting. The fifth NESDB (1982-86) focused too much on the economic exportation and commodification of the market and it neglected women and peasants at the village community level. This is precisely why Bell (1997:72) argues that kan phatthana at times is patriarchal and heavily capitalistic. Personally, I find this ironic given

21 Pruekpongsawalee's (2004:14) investigated the society's legislation at the time and she writes that "[as] Thailand still lacks legislation for equal opportunity employment, employers in both state enterprises and the private sector have the freedom to prescribe qualifications in job advertisements, excluding the equal opportunity clause".

22 Mills (1999:10) explains clearly that although some women comply with this mode of femininity-manipulation of their sexuality-in order to become mobilized, other means are taken into account by many women. She also notes that the manipulation of the said female sexuality is not usually approved by the kinship at home. Nevertheless, due to economic hardships, this unfortunately becomes a matter of flexibility. Like the ruralmigrant labor migration, the departure from the slum community level to a higher level is shown through this particular female character. 
that the plan fell into the same timeline as the UN's declaration on the decade of women $\left(1975^{-1985}\right){ }^{23}$

There is a stark contrast in the patterns of performing femininity between Anek's sister and Khru Somsri. The characteristics of femininity in accordance with kan phatthana discourse vary in temporality and space. Women's participation in the village community, therefore, disintegrates and is scattered. It either goes along with the gender construction of the society or goes against it. I argue that the female characters in Khru Somsri represent the contradiction at both ends of the Madonna-whore stereotype of women against the sociocultural gender sanctions and roles.

The choice Anek's sister makes suggests a dutiful daughter and a sister who upholds her obligations and supports the family. In the film, it is clear that she delivers Anek's message to lawyer Sot and assures him that her brother will not be the target of suspicion by the community's committee. In spite of the filial obligation of a member of the family, she also portrays what Mills calls (1999:19) "fears [of] urban autonomy" that "undermine[s] the sexual propriety and moral safety". The latter, the fear modernity discourse casts over the expected femaleness of Thai women, contradicts what I mentioned earlier, women's "consumption needs and expectations" (20). These are needs that the capitalist-led economy can offer and clearly what Anek's community, Saan Trok Chao Pho Sua cannot have. Due to her inability to resist the materialistic yearnings, she gives in to a new mode of sexuality. ${ }^{24}$ The film thus shows how sexual propriety is being challenged and contested in this discourse of modernity.

At any rate, the age of consumption needs and has expectations that do not impinge upon all women equally. There is always a space where the subjects can negotiate and act in opposition to the hegemonic discourse, which in this case would be the neo-liberalist mindset and the promotion of the monetized economy through the company's plan to evict the locals and replace their land with the department store. A divergent way Khru Somsri chooses to enact her feminine role is portrayed in this film. She defies the culturally sanctioned

23 Pruekpongsawalee (2004:100) writes that: "[due] to the fact that Thailand became a member of the UN after World War II, the UN has become an external factor which has had a positive effect on women's issues in the country". But, as Bell (1997:72) and Tantiwiramonond and Pandey (1996:86), note, the National Economic and Social Development Board (NESDB) did not really recognize women's struggles in the economic affluence period. It did, however, as Pruekpongsawalee (2004:105) states, issued "the long-term women's development plan of 1982-2001 ... [as] first national development plan for women".

24 See also in Mills (1995:256) where she writes on matters in which women's gendered bodies are under closer scrutiny with regards to economic yearns for upward mobility. 
demeanor that is expected from her and we can see that a group of the villagers themselves side with her and her leadership. The effect of modernity and development rhetoric does not seep into the community entirely. Its power is not hegemonic and it paves the way for an alternative femininity for a woman. But, the community works around the kan phattana ideology, an uneven development, in order to achieve the purpose to remain on their land.

Additionally, the character of Khru Somsri disregards the cultural obligation and expected femininity of the society and the gender system altogether. With the completion of eleventh grade from high school, she does not want to leave her community. In fact, she vows to fight for the destitute situation of the children at the school, ${ }^{25}$ the well being and the pride of the locals in the community. Unlike Anek's sister, Khru Somsri embeds herself in cultivating the knowledge to children at the school. Her role as a teacher and an educator represents the development discourse that enhances formal education. She, too, is a force of resistance and disavows kan phattana's materialization of the community. Certainly, she yearns for the locals' prosperity and the children's well-equipped education that can only be attained by materialistic gains in the milieu of rapid economic growth. However, so long as her community can keep its land and self-sufficient way of life, it is plausible that she will not object to the development.

Nevertheless, the land development company does not grant the community any such wish. They will go to any lengths to dismantle the locals' deprecation of their department store construction project, be it lobbying the locals, physical assault, materialistic lures, arson and, eventually, murders. Khru Somsri is the female leader of the community who is not confined to behave in the way that Anek's sister does. By leading the demonstration and negotiating with the state office and its officers countless times she fits Yuval-Davis' (1997:6) thorough examination on the intricate relations between gender and nation that: "non-Westocentric analysis of gender relations cannot assume the boundary between the public and the private as a given". Khru Somsri who has the utmost stubborn and radical temperament and not to be underrated characteristics fights for her community. Her lived experience is individual and resists the cultural obtrusion of modern led development in this instance. This is again in accordance with Yuval-Davis' (1997:7) words:

25 A male drunkard named Thongyoi is the principal of the community's only school. He has no determination to better the living and studying environment of the children at the school. Moreover, at times, he obstructs Khru Somsri and the other teacher's endeavors to educate them. 
women's oppression is endemic and integral to social relations with regard to the distribution of power and material resources in the society. Gender, ethnicity, and class, although with different ontological bases and separate discourses, are intermeshed in each other and articulated by each other in concrete and social relations.

Khru Somsri's resistance towards the state shows that at any rate, gender and nation are not separate. Women's participation in the 1980s kan phatthana is diverse and can be seen at each end of the Madonna-whore dichotomy as discussed earlier. The discursive practices that are hierarchical, male dominated and fall into the patronage type, and the widening economic and intellectual gap between the state and the community levels render both desperation and the need for renegotiation of the gender system in Thai society. The discourse of capital-led materialized Thai society alters gender roles, position and cultural sanctions as being time and space contingent. Once again it is beneficial to consider Yuval-Davis' (1997:43) assertion on the "cultural stuff" that makes up class, community and gender relations. This author argues that socio-cultural elements are "full of internal contradictions, which are used selectively by different social agents in various social projects within specific power relations and political discourses in and outside of the collectivity". As seen in the discussion throughout the chapter, the film Khru Somsri represents the "internal contradictions" in the form of the Others, which include the state's shifting roles and the locals' conflict and principles, renegotiation of gender relations and unequal distribution among the classes.

\section{9 \\ Conclusion}

To conclude, the politics in the 1980 s that had relocated its focus from the rhetoric of counter insurgency to the neo-liberalist export-oriented economic growth contributed to the transformation of the social stratification and the predominantly unequal socio-economic benefits in the form of patron-clientage and crony materialization. The state led discourse of development or kan phattana engendered participation particularly at the community level as the film emphasizes. The nature of the participation discourse is multifarious in its hierarchized positioning and gender relations. The hierarchy does not go unnoticed and the lived experience of the locals is made visible by the elitist producer's articulation himself.

With regard to gender relations, the economic boom and the materialistic yearnings that became instant influxes in Thai society, the film represents Thai 
women as: prolonging their socially expected roles on one hand and being militant and politically active on the other. In the age of economic prosperity, there was an increasing intermittent benefit for people belonging to each class, position and gender relations. As the film portrays, the grassroots' means to voice their struggles for formal education and daily earnings were very little to none. Their struggles to keep their land from commercialized exploitation were in fact unheard. The structural transformation, particularly the capitalization of natural lands for the benefit of the free market did more harm than good in the development ideologue. It also intensified the coerced participation in exchange for monetary gain and coercive gender roles, specifically the re-enactment of feminine demeanor or the renegotiation of it, being reiterated at the expense of the deprived community people, men, women, and children alike.

All in all, the film represents the transformation of society and the disintegrated participation amid the state-led discourse of kan phattana. Specifically, Khru Somsri's depiction of women at the community level and their need for materialistic consumption shows how Thai femininity was challenged, transformed and enmeshed within the historical and temporal period of the Thai socio-economic terrain. Films like Khru Somsri are part of a repertoire that enmeshes the hardships of the underprivileged class fighting for their roots, yet the actualization of the uneven benefits among the classes also reiterates the fact that Thai society in the eighties was being rapidly materialized. Khru Somsri urges us to both sympathize with the scarcity of the locals but at the same time, we have to ponder upon the endemic problems that came with the country's liberalist approach as well.

\section{References}

Bell, Peter F. 1997. Thailand's Economic Miracle: Built on the Backs of Women. In Women, Gender Relations and Development in Thai Society Volume One, edited by Virada Somswasdi and Sally Theobald, pp. 55-82. Chiang Mai: Women's Studies Center.

Busbarat, Pongphisoot, and Creak, Simon. 2015. Re-Examining Self-Reliance: Collective and Individual Self-Making in Rural Thailand since the 1980s. Southeast Asia Research 23.3: 335-356.

Connors, Michael Kelly. 2004. The Asian Economic Miracle and Its Unmaking. In The New Global Politics of the Asia-Pacific, edited by Michael K. Connors, Rémy Davison and Jörn Dosch. pp. 162-179. New York: RoutledgeCurzon.

Errington, Shelly. 1990. Recasting Sex, Gender, and Power: A Theoretical and Regional Overview. In Power and Difference: Gender in Island Southeast Asia, edited by Jane 
Monnig Atkinson and Shelly Errington, pp. 1-58. Stanford, California: Stanford University Press.

Hamilton, Annette. 1993. Cinema and Nation: Dilemmas of Representation in Thailand. East-west Film Journal 7.1: 81-105.

Haughton, James. 2009. Building Modern Communities in Capitalist Thailand. In Tai Lands and Thailand: Community and State in Southeast Asia, edited by Andrew Walker, pp. 44-66. Honolulu: University of Hawaii Press.

Hirsch, Philip. 1990. Development Dilemmas in Rural Thailand. Oxford: Oxford University Press.

McNabb, Scott F. 1988. Stability in Thailand in the Mid-1980's: Anomaly or Long-Term Trend? Asian Thought and Society 13.39: 224-228.

Mills, Mary Beth. 1995. Attack of the Widow Ghosts: Gender, Death, and Modernity on Northeast Thailand. In Bewitching Women, Pious Men: Gender and Body Politics in Southeast Asia, edited by Aihwa Ong and Michael G. Peletz, pp. 244-273. Berkeley: University of California Press.

Mills, Mary Beth. 1999. Thai Women in the Global Labor Force: Consuming Desires, Contested Selves. New Brunswick, N.J.: Rutgers University Press.

Omvedt, Gail. 1986. Women in Popular Movements: India and Thailand during the Decade of Women. UNRISD pp. 211-247.

Phongpaichit, Pasuk, and Baker, Chris. 1995. Thailand, Economy and Politics. Oxford: Oxford University Press.

Pongsapich, Amara. 1997. Feminism Theories and Praxis: Women's Social Movement in Thailand. In Women, Gender Relations and Development in Thai Society Volume One, edited by Virada Somswasdi and Sally Theobald, pp. 3-51. Chiang Mai: Women's Studies Center.

Pruekpongsawalee, Malee. 2004. The Constitutions and the Legal Status of Women in Family Related Laws in Thailand: A Historical Perspectives. In Women's Studies in Thailand: Power, Knowledge and Justice, edited by Suwanna Satha-anand, pp. 88155. Seoul: Ewha Womans University Press.

Reynolds, Craig J. 2002. Thai Identity in the Age of Globalization. In National Identities and Its Defenders: Thailand Today, edited by Craig J. Reynolds, pp. 308-338. Chiang Mai: Silkworm.

Reynolds, Craig J. 2009. The Origin of Community in the Thai Discourse of Global Governance. In Tai Lands and Thailand: Community and State in Southeast Asia, edited by Andrew Walker, pp. 27-43. Honolulu: University of Hawaii Press.

Sirisumpan, Napas. 2001. Thai Women Status in the Period of 2 Decades after the International Women Year (1975-1985). Bangkok: Social Research Institute.

Suehiro, Akira. 1992. Capitalist Development in Postwar Thailand: Commercial Bankers, Industrial Elite, and Agribusiness Groups. In Southeast Asian Capitalists, edited by Ruth McVey, pp. 35-63. New York, Southeast Asia Program. 
Sungsri, Patsorn. 2004. Thai Cinema as National Cinema: An Evaluative History. Doctoral dissertation, Murdoch University, Perth.

Tantiwiramanond, Darunee and Shashi Ranjan Pandey. 1987. The Status and Role of Thai Women in the Pre-Modern Period: A Historical and Cultural Perspective. SOJOURN 2.1: 125-149.

Tantiwiramanond, Darunee and Shashi Ranjan Pandey. 1996. New Opportunities or New Inequalities: Development Issues and Women's Lives in Thailand. Paper presented at the 6th International Conference on Thai Studies Theme VWomen, Gender Relations and Development in Thai Society, 14-17 October, 1996, Chiang Mai.

Turton, Andrew. 1989a. Thailand: Agrarian Bases of State Power. In Agrarian Transformations: Local Processes and the State in Southeast Asia, edited by Gillian Hart, Andrew Turton, and Benjamin White, pp. 53-69. Berkeley: University of California Press.

Turton, Andrew. 1989b. Local Powers and Rural Differentiation. In Agrarian Transformations: Local Processes and the State in Southeast Asia, edited by Gillian Hart, Andrew Turton, and Benjamin White, pp. 70-97. Berkeley: University of California Press.

Vichit-Vadakan, Juree. 1997. Women, Men and Thai Politics. In Women, Gender Relations and Development in Thai Society Volume One, edited by Virada Somswasdi and Sally Theobald, pp. 425-443. Chiang Mai: Women's Studies Center.

Walker, Andrew. 20oga. Modern Tai Community. In Tai Lands and Thailand: Community and State in Southeast Asia, edited by Andrew Walker, pp. 1-23. Honolulu: University of Hawaii Press.

Walker, Andrew. 20ogb. Tai Community on the Move. In Tai Lands and Thailand: Community and State in Southeast Asia, edited by Andrew Walker, pp. 214-220. Honolulu: University of Hawaii Press.

Walker, Andrew. 2010. Royal Sufficiency and Elite Misrepresentation of Rural Livelihoods. In Saying the Unsayable: Monarchy and Democracy in Thailand, edited by Søren Ivarsson and Lotte Isager, pp. 241-265. Singapore: NIAs Press.

Winichakul, Thongchai. 2002. Remembering/Silencing the Traumatic Past: The Ambivalent Memories of the October 1976 Massacre in Bangkok. In Cultural Crisis and Social Memory: Modernity and Identity in Thailand and Laos, edited by Shigeharu Tanabe and Charles F. Keyes, pp. 243-283. Honolulu: University of Hawaii Press. Yuval-Davis, Nira. 1997. Gender \& Nation. London: Sage. 